\title{
THE ECONOMICS OF ON-FARM PROCESSING OF SUNFLOWER OIL
}

\author{
DELMER L. HELGESON and LEROY $W$. SCHAFFNER
}

Vegetable oil as an extender or substitute for diesel fuel is receiving increased attention from farmers. If research confirms that sunflower oil (sun oil) can be used in diesel engines without harmful effects there will be increased interest in how farm operators can obtain vegetable oil and at what cost. Many farmers are interested in providing their own supply of sun oil on the farm, while others may be interested in buying their supply of sun oil from commercial sources.

The objective of this article is to provide information on farm processing costs for three potential sizes of small screw-type presses. Costs were estimated for processing a volume of sun oil sufficient to provide the fuel requirements for an average size farm. An average size farm in North Dakota, based on 1978 data, consists of 1,038 acres, composed of 737 acres in cropland or 71 percent, 245 acres ( 24 percent) in pasture, and 56 acres ( 5 percent) taken up by the farmstead, roads, and miscellaneous land usage. ${ }^{1}$ An average North Dakota farm is estimated to use approximately 4,800 gallons of diesel fuel annually, assuming diesel engines were used for all field, harvest, and livestock operations (Table 1).

Three sizes of screw-type presses were analyzed for on-farm usage ranging from 0.35 ton of whole sunflower seed per day, 1.67 tons per day, and 5.0 tons per day. The processing of 4,800 gallons of sun oil would not require additional labor beyond the individual farm operator. The time required to process 4,800 gallons of sun oil would be approximately 160,31 , and 10 days respectively for the three sizes of presses. The assumption used was the presses would operate eight hours per day plus an additional hour for starting

${ }^{1}$ U.S. Department of Commerce, Bureau of the Census, 1978 Census of Agriculture, Preliminary Report, North Dakota, Washington, D.C., October, 1980. (Farms with sales of $\$ 2,500$ or more were used.)

Dr. Helgeson and Schaffner are both Professor, Department of Agricultural Economics. and shutting the press down. ${ }^{2}$ Hired labor would be necessary when the presses are operated 300 days per year.

Estimated initial investment for equipment, building, and storage costs, obtained from industry sources, were delineated for the three presses. Each press is capable of processing a minimum of 4,800 gallons of sun oil during the winter months when there would be no field operations (Table 2).

The small press had an oil extraction efficiency of 82 percent whie the medium and large presses had extraction efficiencies of 89 percent. These presses extract sun oil from whole sunflower seed without any cooking or heating process which makes the oil extraction efficiency lower than commercial presses, resulting in meal with a higher oil content.

The investment costs include a 5,000 gallon storage tank. This size would hold the sun oil that would be consumed by an average North Dakota farm. This same size was included for the presses operating 300 days per year, the assumption being that several farmers would cooperate in processing and each farmer would have his own storage tank.

Equipment investment costs were based on the assumption that the sunflower seed will be put into a hopper bin, cleaned, moved into another hopper bin, run through the press, and the resulting crude oil moved into a settling tank before processed through a fourmicron filter and moved into a storage tank. The meal will move directly from the press to the storage area. Building size was scaled to accomodate storage of high oil residual meal to a depth not to exceed 5 feet. Three auger design sets were used to elevate the sunflower seed into the cleaner bin, to the hopper bin, and to move the meal from the press into the meal storage area.

${ }^{2}$ These plants were manually operated with no provision included in cost estimates for a fully automated operation. 


\begin{tabular}{|c|c|c|c|c|}
\hline Farm Organization" & Acres & $\begin{array}{l}\text { Units } \\
\text { Number }\end{array}$ & Gallons/Unit ${ }^{\mathrm{b}, \mathrm{c}}$ & $\begin{array}{c}\text { Total } \\
\text { Gallons of } \\
\text { Diesel Fuel Usage }\end{array}$ \\
\hline Wheat & 247 & -. & 4.57 & 1,129 \\
\hline Barley & 61 & -- & 4.73 & 289 \\
\hline Sunflower & 42 & -. & 7.76 & 326 \\
\hline Oats & 28 & .- & 5.52 & 155 \\
\hline Other Row Crops & 29 & -- & 10.32 & 299 \\
\hline Flaxseed & 6 & -- & 5.82 & 35 \\
\hline Summer Fallow & 207 & -- & 5.70 & 1,180 \\
\hline All Hay & 77 & -- & 2.34 & 180 \\
\hline Pasture & 40 & -- & 1.60 & 64 \\
\hline \multicolumn{5}{|l|}{ Livestock } \\
\hline Beef Cows & -.- & 48 & 3.27 & 157 \\
\hline Sheep & -.- & 5 & 1.60 & 8 \\
\hline Hogs & ..- & 8 & 2.63 & 21 \\
\hline Miscellaneous Use & 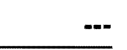 & - & -.. & 957 \\
\hline TOTALS & 737 & 61 & & 4,800 \\
\hline
\end{tabular}

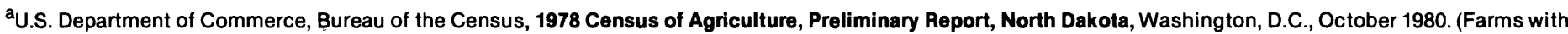
sales of $\$ 2,500$ or more were used.)

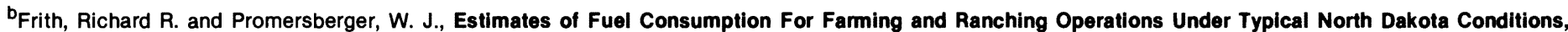
Bulletin 493, Department of Agricultural Engineering, North Dakota State University of Agriculture and Applied Science, Fargo, April, 1974.

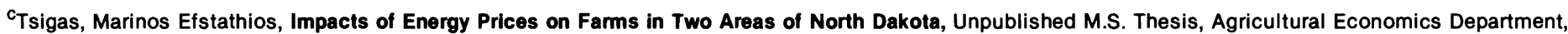
North Dakota State University, Fargo, June 1981.

TABLE 2. INVESTMENT IN EQUIPMENT AND BUILDING FOR THREE SIZES OF ON-FARM PROCESSING PRESSES FOR SUNFLOWER SEED OIL EXTRACTION, NORTH DAKOTA, 1981

\begin{tabular}{|c|c|c|c|}
\hline \multirow[b]{2}{*}{ Item } & \multicolumn{3}{|c|}{ Size of Press } \\
\hline & 0.35 Ton/Day & 1.67 Tons/Day & 5.0 Tons/Day \\
\hline Equinment & & ollars & (2) \\
\hline $\begin{array}{l}\text { Seed Cleaner } \\
\text { Hopper Bin } \\
\text { Press } \\
\text { Oil Settling Tank } \\
\text { Oil Filter } \\
\text { Oil Storage Tanka } \\
\text { Augers and Motors }\end{array}$ & $\begin{array}{r}1,030 \\
1,760 \\
7,165 \\
230 \\
3,735 \\
2,600 \\
1,165 \\
\end{array}$ & $\begin{array}{r}1,030 \\
1,760 \\
7,955 \\
270 \\
5,620 \\
2,600 \\
1,165 \\
\end{array}$ & $\begin{array}{r}1,170 \\
2,600 \\
14,745 \\
370 \\
5,755 \\
2,600 \\
1,165 \\
\end{array}$ \\
\hline Total Equipment Investment & 17,685 & 20,400 & 28,405 \\
\hline Building & $\underline{11,250^{b}}$ & $11,250^{b}$ & $\underline{13,100^{\circ}}$ \\
\hline $\begin{array}{l}\text { Total Investment in Equipment } \\
\text { and Building }\end{array}$ & 28,935 & 31,650 & 41,505 \\
\hline
\end{tabular}

$\mathrm{a}_{5,000}$ gallon capacity, a one year supply for the average farm.

bSteel building about 1,200 square feet not insulated. The meal storage requires more space given the high oil content, meal should not exceed five feet in depth while in storage.

'Steel building about 1,400 square feet not insulated.

SOURCE: Foreign and domestic industrial firms. 
Estimated equipment costs ranged from $\$ 17,685$ for the 0.35 ton per day press to $\$ 28,405$ for the 5.0 tons per day press. Estimated building investment costs ranged from $\$ 11,250$ for the two smallest presses to $\$ 13,000$ for the 5.0 tons per day press. Buildings, in each instance, were uninsulated steel structures. If heat was desired for the press area for cold weather operation, an additional investment allowance would need to be made for insulation and a heat source.

The estimated processing costs for 4,800 gallons of crude sun oil for each of three sizes of presses amendable to on-farm processing is provided in Table 3. Total estimated processing costs per gallon of crude sun oil came to $\$ 4.33$ for the 0.35 ton per day press, $\$ 2.82$ for the 1.67 tons per day press, and $\$ 2.87$ for the 5.0 tons per day press. These costs include a charge for all the resources used in producing sun oil.

There is a cost variation of $\$ 1.46$ per gallon from the smallest to the largest press considered in this analysis when all the costs are included. Total time required to produce 4,800 gallons of crude sun oil varied from 1,440 hours for the smallest press, 280 hours for the medium sized press, to only 93 hours for the largest press. Translated into nine-hour operating days, this represents 160 days or 5.3 months for the smallest press ( 0.35 ton/day), 31 days for the medium sized press ( 1.67 tons/day), and 10 days or about one-third of a month for the largest press (5.0 tons/day).

Depreciation and interest on the equipment was amortized over a 15 -year period at 10 percent interest paid quarterly. It is recognized that the machines are used only a very limited time to produce the 4,800 gallons of sun oil, 53 percent for the small press, 10 percent for the medium, and only 3.5 percent for the large press. If depreciation was prorated only for the time used, depreciation would be charged far beyond its likely technologically efficient life. For example, the large press would last for 428 years $(15$ years $/ .035=428)$. No salvage value was taken since after 15 years new technology may leave the equipment with very little value to recover.

As a means of providing for a wide range of alternatives in analyzing the cost structure, it was assumed that some farmers may already have a building suitable to house the press and a zero opportunity cost was considered for the operator's labor (Table 3). By deleting building depreciation and the labor charge, the resulting cost per gallon of crude sun oil is $\$ 2.57$ for the smallest press, $\$ 2,27$ for the medium press, and $\$ 2.48$ for the large press.

When the on-farm sized presses are operated 300 nine-hour days per year, (eight hours for the press and one hour to start and stop the press at the beginning and end of the day), the volume of crude oil processed totals 9,000 gallons for the small press, 46,272 gallons for the medium press, and 138,696 gallons for the largest press (Table 4). This annual volume translates into a crude sun oil supply that would support the requirements of
1.87 average size North Dakota farms for the small press, 9.64 average size farms for the medium press, and 28.90 average size farms for the largest press.

The processing cost per gallon of crude sun oil decreases when the presses can be operated full time (300 days). The reduction in costs from part time to full time operation of the press is $\$ 0.40$ per gallon for the small press, $\$ 0.79$ per gallon for the medium press, and $\$ 1.13$ for the large press. These cost reductions are for the situation where all costs are included.

A by-product of processing sunflower seed for oil is the sun meal. The amount of meal produced depends on the efficiency of the press to get oil from the sunflower seed and the length of time the press is operated. A range of 33 to 37 tons of meal is obtained when processing for 4,800 gallons of crude sun oil by the three sizes of on-farm presses. When the presses are operated 300 days, the amount of meal obtained varied from 71 tons for the small press to 966 tons for the largest press.

Credit was given for the meal produced at $\$ 101.70$ per ton in the cost analysis. This was the January-March 1981 average spot price at Minneapolis for 28 percent protein sun meal. Meal produced by the small on-farm presses is not the same quality as commercial meal because of the higher oil content. There is about 18 percent oil in the meal from the small press and 11 percent oil in the meal from the medium and large presses. A more accurate consideration would be to discount the $\$ 101.70$ per ton spot market price used in this analysis. This was not done because there is limited market guidance to base a discount on. If the meal cannot be used on the farm where processed or sold locally, the other alternative use is for fertilizer. The meal can be valued at $\$ 42.66$ per ton at current fertilizer prices. ${ }^{3}$ Experiments on sun meal of high oil content have not been completed to provide an accurate discounted meal price. The other possibility is this meal may command a price locally equivalent to the spot market price used in this analysis.

The estimated costs for the three presses operating 300 days per year capture some economies of size. ${ }^{4}$ The estimated cost per gallon of crude sun oil is reduced from $\$ 3.93$ per gallon for the small press to $\$ 1.74$ per gallon for the 5.0 tons per day size press. The assumption used for the presses, when operating 300 days, is that the farmer would collect his supply of crude sun oil when it was processed, so no additional storage tanks beyond 5,000 gallons were included in the investment costs.

How many animal units of livestock will the meal from the small on-farm presses support? This depends on the the type of ration a farmer is feeding. If he is

${ }^{3}$ Nitrogen was valued at $\$ 0.31$ per pound, phosphate at $\$ 0.28$ per pound, and potash at $\$ 0.13$ per pound of actual ingredients. 


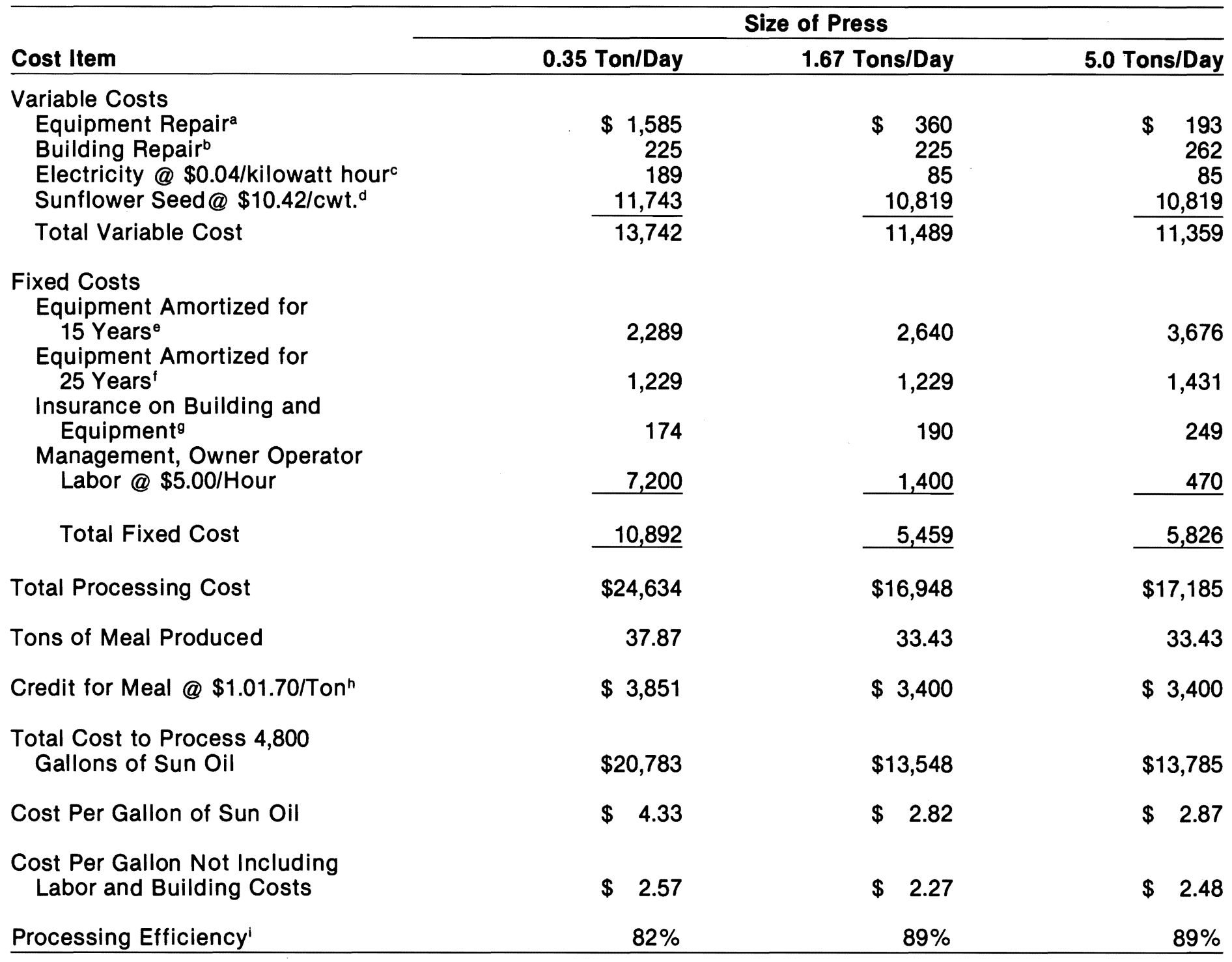

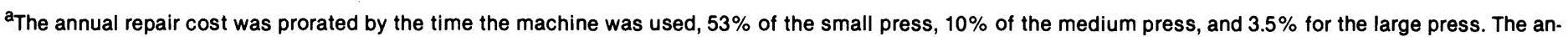
nual equipment repair costs were charged on a percentage basis of new cost as follows: press $27 \%$, filter $21 \%$, other equipment $4 \%$.

b Steel building repair charged at $2 \%$ of new cost.

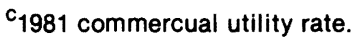

$d_{1976-80}$ average price received by farmers

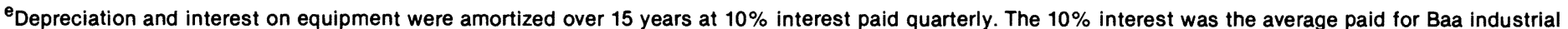
bonds for 1975-79.

'Depreciation and interest on the building were amortized over 25 years at $10 \%$ interest paid quarterly.

$9_{\$ 6.00 / \$ 1,000}$ charged on equipment and building.

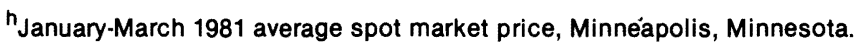

iPercent of oil removed.

feeding alfalfa hay and barley or oats, the amount of protein supplement needed is very little or none. If the ration is corn silage and corn, then 2 or 3 pounds of meal per animal unit could be used. Table 5 shows the animal units that can be supported using rations containing 1,2 , and 3 pounds of sun meal per day. The feeding period was 180 days. This analysis indicates that if most farmers process their own crude sun oil they will have a surplus of meal to dispose of. The small press processing 4,800 gallons of sun oil could support from
122 to 367 animal units depending on whether they were feeding 1,2, or 3 pounds of meal in the ration. About 16 percent of the farms in North Dakota with sales of $\$ 2,500$ or more have livetock herds of 100 head or more. Only about half of the farms in North Dakota reported cattle and calves in 1978.

${ }^{4}$ Economics of size, as used here, means reductions in total cost per unit of production resulting from changes in the size and quantity of resources employed. 


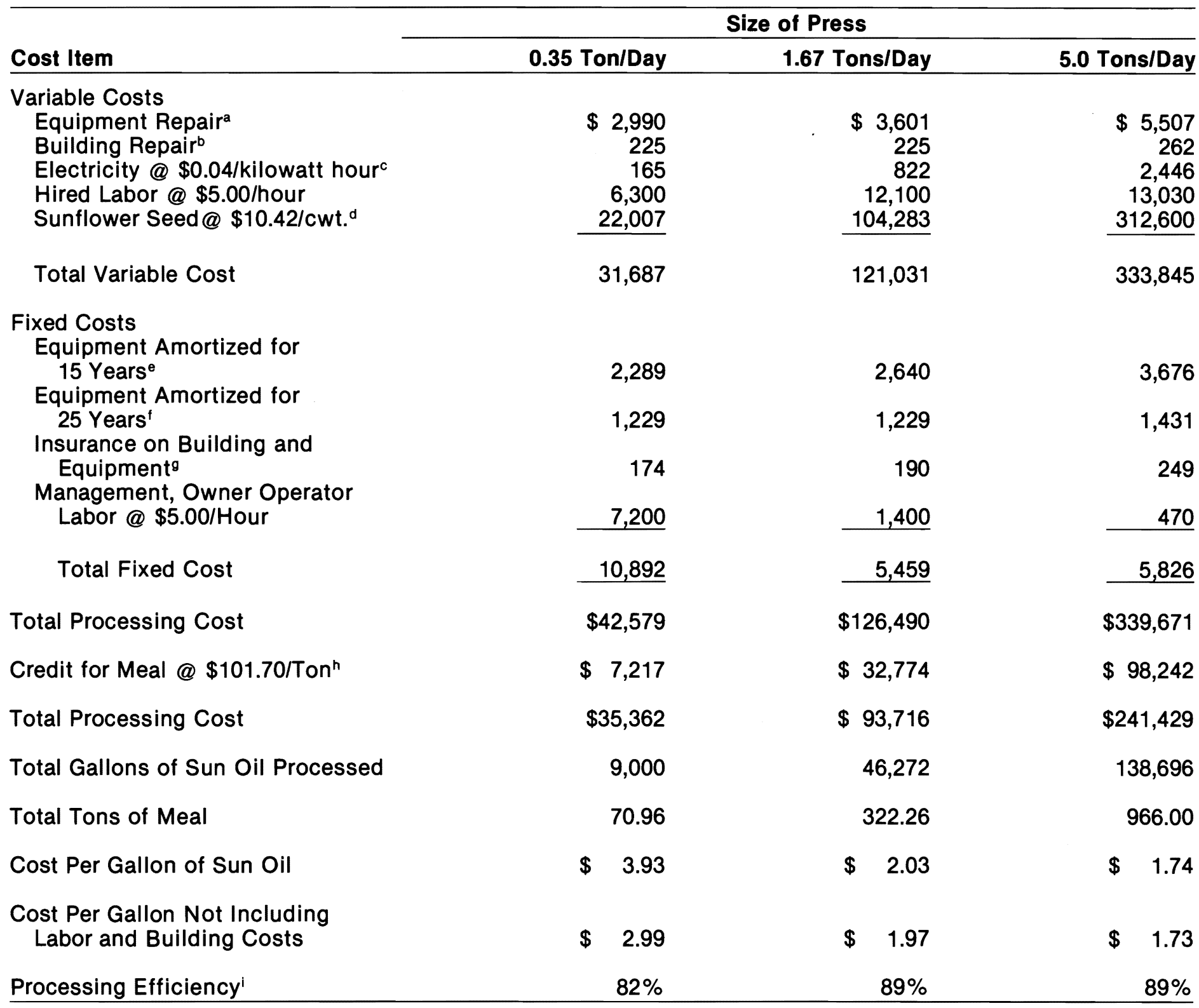

${ }^{a}$ The annual equipment repair costs were charged on a percentage basis of new cost as follows: press $27 \%$, filter $21 \%$, other equipment $4 \%$.

${ }^{b}$ Steel building repair charged at $2 \%$ of new cost.

$c_{1981 \text { commercual utility rate. }}$

$d_{1976-80}$ average price received by farmers.

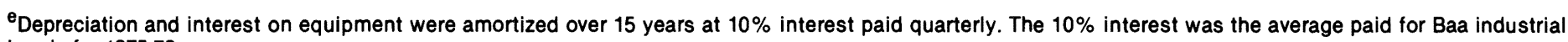
bonds for 1975-79.

${ }^{f}$ Depreciation and interest on the building were amortized over 25 years at $10 \%$ interest paid quarterly.

9 $\$ 6.00 / \$ 1,000$ charged on equipment and building.

hJanuary-March 1981 average spot market price, Minneapolis, Minnesota.

'Percent of oil removed.

There will be about 620,000 tons of sun meal produced annually in North Dakota in the near future when three commercial sun oil plants are all operating. This is more than is consumed in the state. If all of the beef and dairy stock consumed some sun meal, the consumption could reach 248,000 tons, only about 40 percent of the potential supply of meal from commercial plants. Meal from the on-farm presses would have to compete in this market if there was not enough livestock on the farm where sunflower is processed for oil to consume the meal. 
bought 76 percent of the tracts that had been parts of another farm, plus 65 percent of what had been separate farm tracts and some other tracts. There was a large net transfer of land to add-on or expansion buyers and a one-tract increase in those in other uses.

The sharp decline was in the number of tracts entering and then leaving the market as separate farms. This study showed 98 separate farms entered the market but only 32 left for use as separate, independent farms. This group picked up eight large tracts which had been parts of another farm.

\section{A Longer View of Land Value Changes}

The index of farmland values is based on two surveys a year conducted by the U.S. Department of Agriculture. The two surveys go to two somewhat different groups but measure changes in the farmland market in November and February. The February index was shifted to the 1977 base $=100$ to give readers a better feel for price changes. The November survey was ended in 1980. Figures for 12 years are presented below for North Dakota and the "48 states."

\section{USDA Index of Farmland Values}

\begin{tabular}{|c|c|c|c|c|}
\hline \multirow[b]{2}{*}{ Year } & \multicolumn{2}{|c|}{ North Dakota } & \multicolumn{2}{|c|}{48 States } \\
\hline & $\begin{array}{c}\text { February/March } 1 \\
(1977=100)\end{array}$ & $\begin{array}{l}\text { November } 1 \\
(1967=100) \\
\end{array}$ & $\begin{array}{c}\text { February/March } \\
(1977=100)\end{array}$ & $\begin{array}{r}1 \text { November } 1 \\
(1967=100)\end{array}$ \\
\hline $\begin{array}{l}1981 \\
1980\end{array}$ & $\begin{array}{l}145 \\
136\end{array}$ & & $\begin{array}{l}158 \\
145\end{array}$ & \\
\hline 1979 & 119 & 434 & 125 & 379 \\
\hline 1978 & 106 & 385 & 109 & 332 \\
\hline 1977 & 100 & 360 & 100 & 296 \\
\hline 1976 & 89 & 332 & 86 & 269 \\
\hline 1975 & 76 & 290 & 75 & 230 \\
\hline 1974 & 55 & 229 & 66 & 205 \\
\hline 1973 & 41 & 168 & 53 & 170 \\
\hline 1972 & 36 & 134 & 47 & 141 \\
\hline
\end{tabular}

Prior to 1972 the indices reflected only small increases per year in farmland values. The rise in land values accelerated in 1973, slowed in 1975-78, accelerated again in 1978, and showed a small decline in the 1979-80 period.

Changes in land values can be measured in current dollars or adjusted for what is happening to the dollar. Which index to use to adjust land values for changes in the dollar is a problem. The Consumer Price Index is an appropriate index to use for adjusting prices of consumer-oriented retail goods, but land has several types of demand. Buying land as a producer of raw material suggests using a wholesale or primary producers index. Some buy land for consumptive purposes (scenic home site) and others for speculative, developmental, hedge, and many other reasons.

What does the future hold for land values? Current economic forces affect the various landowner and buyer groups in various and sometimes conflicting ways. Agriculture is not homogeneous, nor are the participants in the farmland market, and society has not articulated its various and sometimes conflicting goals clearly.

Reporters were asked about their expectations for land values in 1982 . One-half expected about the same values at the end of 1982 as the survey in November 1981. One-fourth expect to see some declines in 1982 land values which is up greatly from the 6 percent so reporting in the 1980 survey. The decline in optimism occurred in those expecting a 5 percent or larger increase in 1982 land values. This optimistic group declined in 1981 to 22 percent from 51 percent in the 1980 survey. The mood of the reporters is much more conservative or less optimistic than last year.

continued from 7

TABLE 5. NUMBER OF ANIMAL UNITS REQUIRED TO CONSUME THE SUN MEAL PRODUCED BY THE ON FARM PRESSES USING VARIOUS FEEDING RATES.

Tons of Meal Produced

\begin{tabular}{|c|c|c|c|}
\hline $\begin{array}{r}33^{\mathrm{b}} \\
38^{\mathrm{c}} \\
71^{\mathrm{d}} \\
322^{\mathrm{e}} \\
966^{\mathrm{f}}\end{array}$ & $\begin{array}{r}367 \\
422 \\
789 \\
3,578 \\
10,733\end{array}$ & $\begin{array}{r}183 \\
211 \\
394 \\
1,789 \\
5,367\end{array}$ & $\begin{array}{r}122 \\
141 \\
263 \\
1,193 \\
3,578\end{array}$ \\
\hline \multicolumn{2}{|c|}{${ }^{\text {a }}$ Sun meal supplement was fed for 180 days. } & \multicolumn{2}{|c|}{${ }^{d}$ Meal production from the 0.35 ton/day press operatying 300 days. } \\
\hline \multicolumn{2}{|c|}{$\begin{array}{l}\text { b Meal production from the } 1.67 \text { and } 5.0 \text { tons/day presses producing } 4,800 \\
\text { gallons of sun oil. }\end{array}$} & \multicolumn{2}{|c|}{${ }^{e}$ Meal production from the 1.67 tons/day press operating 300 days. } \\
\hline \multicolumn{2}{|c|}{${ }^{c}$ Meal production from the 0.35 ton/day press producing 4,800 gallons of sun oil. } & \multicolumn{2}{|c|}{${ }^{f}$ Meal production from the 5.00 tons/day press operating 300 days } \\
\hline
\end{tabular}

Number of Animal Units Pounds/Day of Sun Meala 12 